\title{
Non-destructive analysis of a pre-hispanic basketry collection from La Paz, Bolivia
}

\section{Análise não-destrutiva de uma coleção de cestaria pré-hispânica de La Paz, Bolivia}

\author{
Fábio Luiz Melquiades ${ }^{1}$; Juan Villanueva ${ }^{2}$; Fábio Lopes $^{3}$; Jorge Lisme ${ }^{4}$; \\ Eduardo Inocente Jussiani ${ }^{5}$; Carlos Roberto Appoloni ${ }^{6}$
}

\begin{abstract}
Ancient cultures in South America have been manufactured basketry artefacts for human use. However, the pre-Hispanic basketry is scarce and at present, there are few analytical studies on these objects. This study presents an analytical investigation of a collection of ancient baskets from Museo Nacional de Etnografía y Folklore (MUSEF), La Paz, Bolivia employing portable X-ray Fluorescence and portable Raman Spectroscopy. The analyses were performed in situ with non-invasive and non-destructive methods. The chemical elements $\mathrm{K}, \mathrm{Ca}, \mathrm{Ti}, \mathrm{Mn}, \mathrm{Fe}, \mathrm{Zn}$, and $\mathrm{Sr}$ were identified in all the samples. The principal component analysis tends to separate the basket pieces in two groups: one of them is related to stylistic shape of the Middle Horizon, Titicaca Lake basin, and the other was inconclusive. This was the first time that tinctures used in Andean pre-Hispanic basketry from the MUSEF collection were chemically evaluated and the results added historical and archaeological context to the objects.
\end{abstract}

Keywords: X-ray Fluorescence. Raman spectroscopy. Archaeometry. Andean altiplano. Basket weaving.

\section{Resumo}

\begin{abstract}
As culturas antigas da América do Sul produziram artefatos de cestaria para uso humano. No entanto, cestaria pré-hispânicas são escassas e até o momento, existem poucos estudos analíticos nestes objetos. Este estudo apresenta uma investigação analítica de uma coleção de oito cestos antigos do Museo Nacional de Etnografía y Folklore (MUSEF), La Paz, Bolívia, empregando Fluorescência de raios X portátil e Espectroscopia Raman portátil. As análises foram realizadas in situ com metodologias não invasivas e não destrutivas. Os elementos químicos identificados nas amostras foram $\mathrm{K}, \mathrm{Ca}, \mathrm{Ti}, \mathrm{Mn}, \mathrm{Fe}, \mathrm{Zn}$ e Sr. A análise de componentes principais indicou a tendência de separação dos artefatos em dois grupos: um deles está relacionado ao formato estilístico da bacia do Lago Titicaca, e o outro grupo é de origem inconclusiva. Este artigo apresenta o primeiro estudo com avaliação química dos pigmentos utilizados na cestaria pré-hispânica Andina do MUSEF e os resultados adicionaram contexto histórico e arqueológico aos objetos.
\end{abstract}

Palavras-chave: Fluorescência de raios X. Espectroscopia raman. Arqueometria. Altiplano andino. Tecelagem de cestas.

\footnotetext{
${ }^{1}$ Prof. Dr., Laboratório de Física Nuclear Aplicada, Depto. de Física, UEL, Londrina, Paraná, Brasil, E-mail: fmelquiades@uel.br 2 Me., Museo Nacional de Etnografía y Folklore, La Paz, Bolivia, E-mail: juan.villanuevacriales@ gmail.com

${ }^{3}$ Prof. Dr., Laboratório de Física Nuclear Aplicada, Depto. de Física, UEL, Londrina, Paraná, Brasil, E-mail: fabiolopes@uel.br

${ }^{4}$ Prof. Dr., Physical Sciences and Alternative Energies Career, La UPEA, El Alto. Bolivia, E-mail: lismeticona@yahoo.com

${ }^{5}$ Prof. Dr., Laboratório de Física Nuclear Aplicada, Depto. de Física, UEL, Londrina, Paraná, Brasil, E-mail: inocente@uel.br

${ }^{6}$ Prof. Dr., Laboratório de Física Nuclear Aplicada, Depto. de Física, UEL, Londrina, Paraná, Brasil, E-mail: appoloni@uel.br
} 


\section{Introduction}

Basket weaving or Basketry is the process of weaving fibrous or pliable wood materials into artefacts for human use. Basketry is common to most human societies, being the ancient populations of South America no exception in this regard (CONNOLLY, 2013). However, due to the bad preservation of organic materials in the climatic environment of the Andean mountains and eastern valleys, examples of pre-Hispanic basketry remain scarce. As a result, its study is much less advanced in relation to inorganic materials such as pottery or lithic tools.

Bolivian archaeology has paid little attention to basketry in general. Most research is related to indirect evidence, such as imprints of basketry used as support for pottery manufacturing, in cases such as the Wankarani formative in the central Altiplano (ROCABADO, 2001) and the Amazonian Moxos region (BETANCOURT, 2015). There is circumstantial mention to basketry fragments from caves or burial towers, especially of basketrywoven wrappings for human corpses (SAGÁRNAGA, 2014). There are archaeological sites recognized for the presence of basketry fragments and other organic material, such as Alcaya in the central Altiplano, but there are not systematic, published reports of their content.

One of the few archaeological contexts in which complete baskets have been found is Escaramayu cave, near Pulacayo, in the southern Altiplano. Given the association of these materials with textile and metallic items stylistically related to Tiwanaku culture, this context is dated to the Middle Horizon (ca. AD 500 - 1100). Descriptions of these basketry-made bowls and vases are rather basic, although they assert that some pieces display Tiwanakustyle iconography, while others do not (AGÜERO, 2007; BERENGUER, 2000).

Sadly, modern times have seen the looting of burial caves and towers, leading to the formation of private collections all around the Andean region. Some of these collectors later donated their artefacts to public museums. As a result, some museums guard interesting examples of pre-Hispanic basketry, put deprived of archaeological context. Therefore, an in-depth study of the technical attributes and raw materials of these objects may increase the present acknowledgment of Andean pre-Hispanic basketry.

In this sense, non-destructive analytical techniques for the study of cultural heritage objects is crucial, allowing the characterization of raw materials, and providing comparative information on the homogeneity/heterogeneity of the sample set under evaluation. This may lead to initial classifications and provenance hypothesis.

In the present study two techniques were used, both with portable equipment, in situ at the museum. The first one was portable energy dispersive X-ray fluorescence (pXRF) which provides a multi-elemental analysis of inorganic elements after the excitation of the samples with an X-ray beam. It is one of the most used techniques for elemental analysis of metal artefacts, ceramics, manuscripts, statues, paintings, and other objects of the cultural heritage (APPOLONI, 2013; MELQUIADES et al., 2019; MOHOLY-NAGY et al., 2013).

Qualitative and quantitative information about the elemental composition of the materials may be obtained with this methodology (CESAREO; CASTELLANO; CUEVAS, 1998; CORBEIL; POTTS; WEST, 2009; PARREIRA et al., 2009). It was also used Raman Spectroscopy which states a molecular fingerprint of the sample based on the inelastic scattering of monochromatic light. This paper presents the characterization of an ancient baskets collection from Museo Nacional de Etnografía y Folklore (MUSEF), La Paz, Bolivia. The objective of this research was to investigate the samples employing pXRF and Raman Spectroscopy to access their inorganic and organic composition to aggregate information to the historical and archaeological context of the objects.

\section{Experimental}

\section{Description of the Basket sample}

Eight pieces of Baskets with several sizes, different shapes, and conservation conditions were investigated. The samples had bands and/or stitches in different shades of its raw material. Usually, the shades were black, brown red, and orange. All the samples are attributed to the PreHispanic period. The provenance is unknown, but presumably they are from Bolivian Altiplano, with exception of sample 19477 which presumably came from Bolivian inter-Andean valleys. All the pieces were probably weaved with stipa ichu (an Andean Aliplano typical vegetable fiber) as suggested a comparison with similar, contemporary baskets of MUSEF, analysed macroscopically by botanists from Herbario Nacional de Bolivia (HURTADO, 2017). The coiling technique was employed in its manufacture (ADOVASIO, 2010). The samples description is presented in Tables 1 and 2 . 
Table 1 - Pre-Hispanic basket samples from MUSEF. $N$ is the number of measurements performed with the portable $\mathrm{XRF}$ equipment in the object.

\begin{tabular}{llll}
\hline Code & Description & $N$ & Sample photography \\
\hline 03810 & Basket with a flat base and open, & 3 \\
& bowl-like shape, made in vegetable \\
& fiber. Decoration based on wide, full- \\
& coloured panels, creating apparently \\
& complex zoomorphic motifs, with \\
& coloured fiber, using red and black \\
pigments
\end{tabular}

03811 Basket with a flat base and open, vase-like shape, made in vegetable fiber. Decoration based on small, checkered squares, creating a regular scale-like pattern, with coloured fiber, using red and black pigments.

03812 Basket with a flat base and open, undefined shape, made in vegetable fiber. Decoration based on small, checkered squares, creating a regular scale-like pattern, with coloured fiber, using red and black pigments.

03814 Basket with a flat base and open, bowl-like shape, made in vegetable fiber. Decoration creating a pattern of interconnected diamonds, with coloured fiber, using red and black pigments.

03819 Basket with a flat base and open, bowl-like shape, made in vegetable fiber. Decoration creating a sequence of stylized camelids, with coloured fiber, using red and black pigments.

19477 Basket with narrow, reinforced base and open, cup-like shape, made in vegetable fiber. Decoration concentrated near the border, creating a geometrical motif, with coloured fiber, using black pigment.

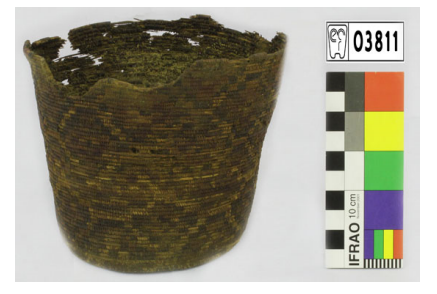

6

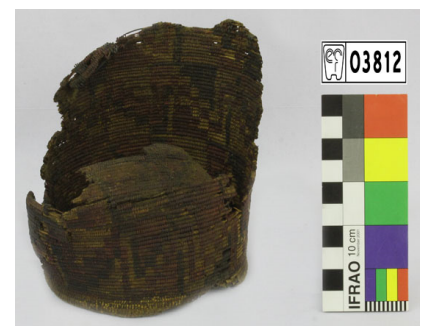

4

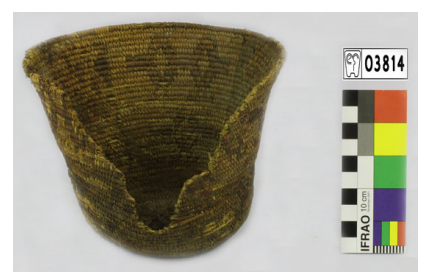

3

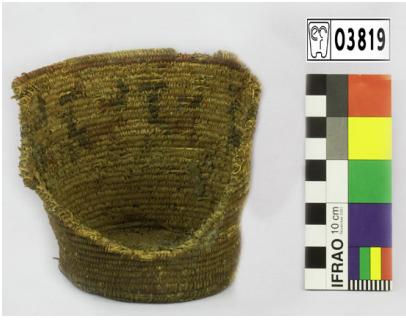

3

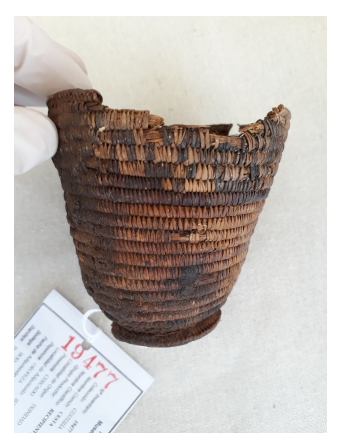


Table 2 - Continuation of Table 1.

\begin{tabular}{ll}
\hline Code & Description
\end{tabular}

Source: The authors.

\section{Analytical techniques}

\section{Energy dispersive $X$-ray fluorescence}

pXRF device was employed as a first stage analytical investigation due to its non-destructive and multielement features, which makes it suitable to guide the use of other methodologies.

The pXRF equipment is a laboratory-made system projected in the Applied Nuclear Physics Laboratory of the State University of Londrina (LFNA/UEL). It uses an acrylic stand that guarantees fixed measurement geometry. The system consists of a mini-X-ray tube for excitation (4W, Ag target, $50 \mu \mathrm{m} \mathrm{Ag} \mathrm{filter,}$ Moxtek Inc.) and a Si-PIN X123 detector (FHWM $153 \mathrm{eV}$ resolution for $5.9 \mathrm{keV} \mathrm{Mn}$ line, $12.5 \mu \mathrm{m} \mathrm{Be}$ window, Amptek Inc.). Measurements conditions were $28 \mathrm{kV}, 10 \mu \mathrm{A}$ during $200 \mathrm{~s}$ of exposition time. The portable equipment was taken to La Paz, Bolivia and the measurements performed in the MUSEF Conservation Laboratory.

In all the samples were performed at least 3 measurements. One measurement in points without pigmentation, ordinarily in its base and the other in pigmentation points when available. As a function of the weave of the wood used in its manufacture, none of the samples offered a flat surface for measurement. In fact, the pXRF technique is strongly de- pendent on measurement geometry. It means that the distance sample-equipment must be ideally the same. This condition was impossible to be obtained in these measurements due to the circular shape of the objects and due to its surface irregularities.

Figure 1 presents the measurement configurations. In order to verify the geometry influence, spectra normalization was performed using the Argonium (Ar) peak and the final result was not altered. So the geometry was not a first-order problem, although it was undoubtedly one of the uncertainty sources.

The qualitative data analysis consisted of the peaks area evaluation in each spectrum. The net area with its deviation and background area were determined for each element detected. The peak to background ratio was calculated in order to certify the presence or absence of the element. A ratio higher than 3 is enough to characterize the presence of the element with robust statistical significance (VAN GRIEKEN; MARKOWICZ, 2002).

\section{Portable Raman spectroscopy equipment}

The portable Raman spectrometer used in the measurements was the Raman Inspector, Deltanu Company from the Applied Nuclear Physics Laboratory of the State University of Londrina (LFNA/UEL). The equipment has a $120 \mathrm{~mW}$ and $785 \mathrm{~nm}$ laser with a resolution less than $8 \mathrm{~cm}^{-1}$ and $200-2000 \mathrm{~cm}^{-1}$ spectral range. 
Figure 1 - Example of a measurement in the base of one of the samples using the pXRF equipment.

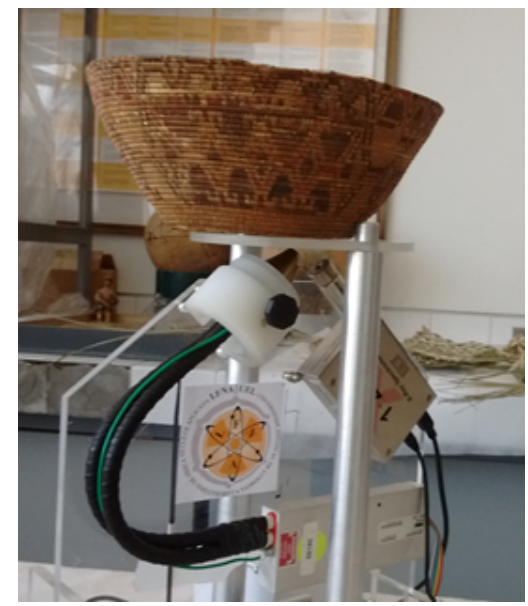

Source: The authors.

\section{Results and discussion}

\section{Elemental analysis by $p X R F$}

The elements K, Ca, Ti, Mn, Fe, Zn, and Sr were identified in all the samples. In general, the highest intensities were from $\mathrm{Fe}, \mathrm{Ca}$, and $\mathrm{Sr}$, respectively. Cupper and $\mathrm{Pb}$ were found in code samples 19477 and 03869, respectively, see Tables 1 and 2 .

Figures 2 to 9 presents the spectra and the peaks net area comparison between the raw material and the pigments for the eight baskets described in Tables 1 and 2 . The error bars indicate the standard deviation in the net intensity.

In sample 03810, it was noted a higher $\mathrm{Ca}, \mathrm{Fe}$ and $\mathrm{Sr}$ intensity in the base measurements compared to the side raw material. No clear differentiation between the black pigment and raw material was noted. In one of the sides of sample 03811 there is an increase in $\mathrm{Ca}$ and $\mathrm{Sr}$ which could indicate the use of bone black pigment. Moreover, the increase in $\mathrm{Fe}$ would be related to black iron oxide (Fe3O4).

In sample 03812 two measurement points presented high Fe intensity, but no clear differentiation between pigment and raw material was noted. It is supposed that the pigments are organic compounds based which cannot be measured by pXRF. The intensity differences in the scattering region of the spectra $(16-26 \mathrm{keV})$ are due to organic compounds (light elements) and geometry positioning. In sample 03814 the black pigment is enriched with $\mathrm{K}, \mathrm{Ti}$ and $\mathrm{Fe}$.
Sample 19477 is characterized by $\mathrm{Cu}(8.04 \mathrm{keV})$ presence. In this sample the black pigment present higher $\mathrm{K}$, $\mathrm{Ca}$ and $\mathrm{Sr}$ intensities compared with the other two points. Sample 03869 is characterized by $\mathrm{Pb}$ presence in the side points of the sample. Lead could be an indicative of environmental contamination from air dust or from car exhaustion (fuel). Cupper could be from dust or mineral provenance.

A relevant point is that the results have allowed to hypothesize the organic composition of the pigments because in several samples it was not possible to infer differences due to inorganic elements between the raw material and pigmentation regions. The differences in organic composition due to light elements (e.g. C, N, O) can be inferred by differences in the scattering peaks intensity. It is well known that the scattering peaks due to the X-ray source carry on information from the "dark matrix" i.e. from the content of organic compounds (VAN GRIEKEN; MARKOWICZ, 2002).

It is important to notice that all of these baskets have been donated to the Museum from earlier owners, who were basically collectors or antiquarians. Thus, air conditions during the decades previous to the entering of the pieces to the Museum are impossible to determine, being air contamination a perfectly logical possibility. The MUSEF restorers attested that disinfestation sprays were used in the organic materials deposit where the baskets are commonly stored. However, the chemistry of the products that have been used for decades is $\mathrm{Pb}$ and $\mathrm{Cu}$ free, as reported by MUSEF staff. The disinfectant is basically a mixture of Aluminum phosphide and Ammonium carbamate. In addition, the patrimonial objects are temporarily covered with plastic during the aerial dispersion of the products.

It was not possible to identify an element that would allow the differentiation between raw material and pigments which indicates organic sources for the pigments production. The presence of the inorganic elements are supposed to be from the wood raw material.

\section{Principal component analysis with pXRF data}

As mentioned before, the geometry of measurement due to inhomogeneity of the weaved wood and due to the object's shape turns difficult the spectra comparison. This problem is minimized when evaluation the spectra from the base of each sample, i.e. the measurement in the external bottom of each basket. 
Figure 2 - (a) Spectra and (b) peaks net area comparison for sample 03810.

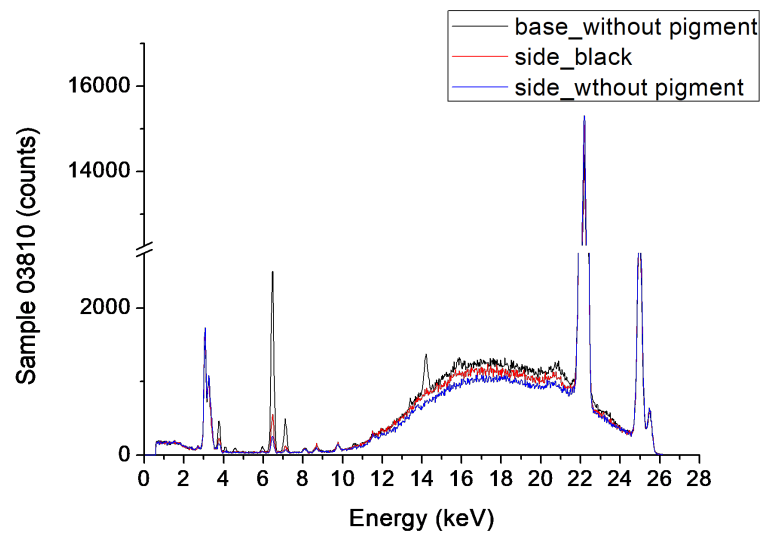

(a)

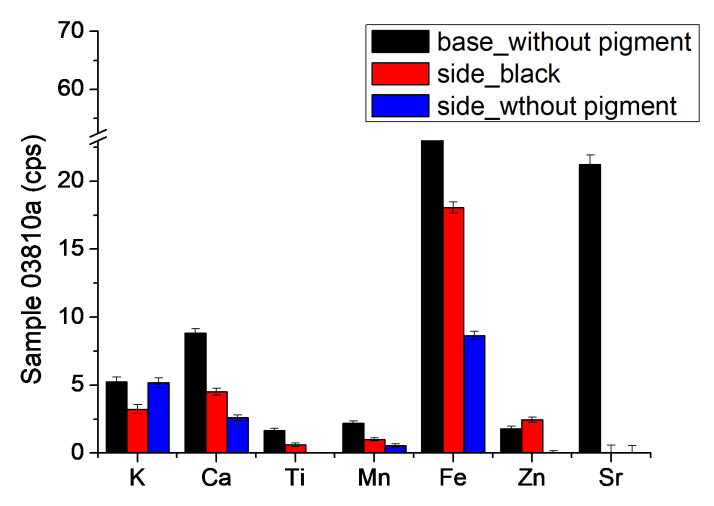

(b)

Source: The authors.

Figure 3 - (a) Spectra and (b) peaks net area comparison for sample 03811.

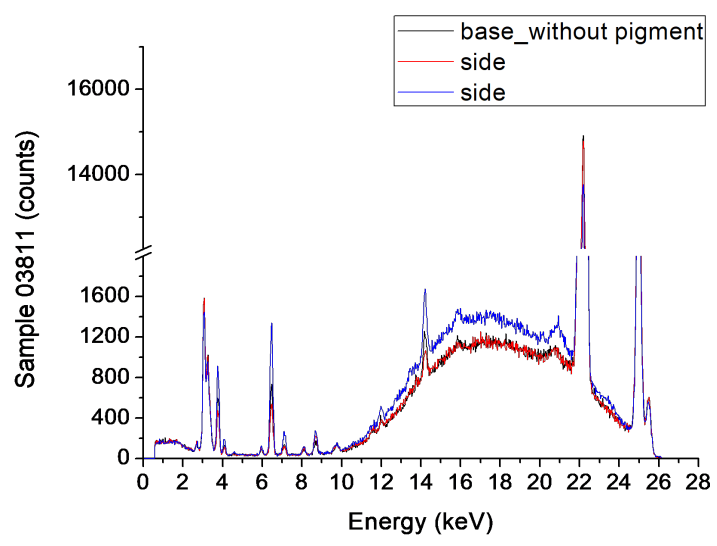

(a)

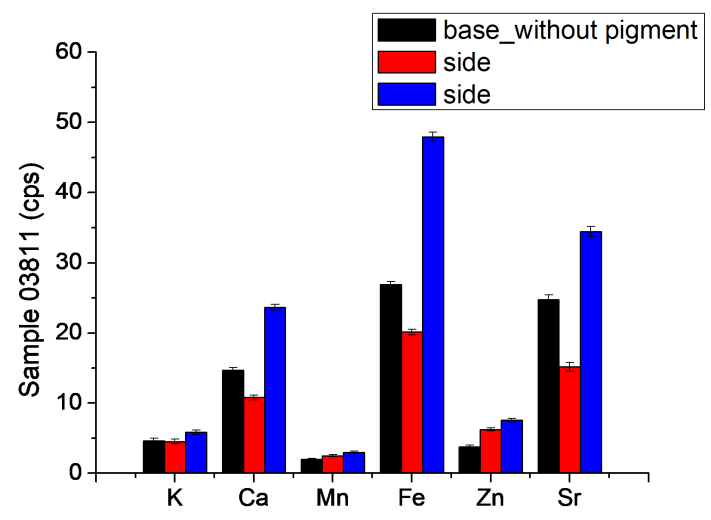

(b)

Source: The authors.

Figure 4 - (a) Spectra and (b) peaks net area comparison for sample 03812.

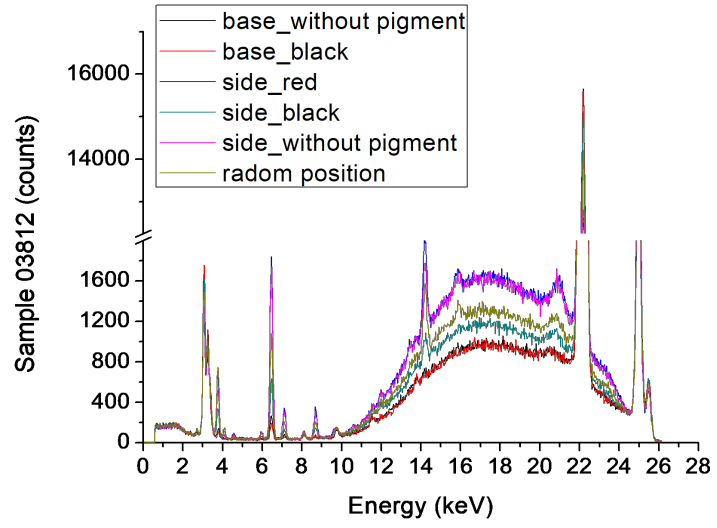

(a)

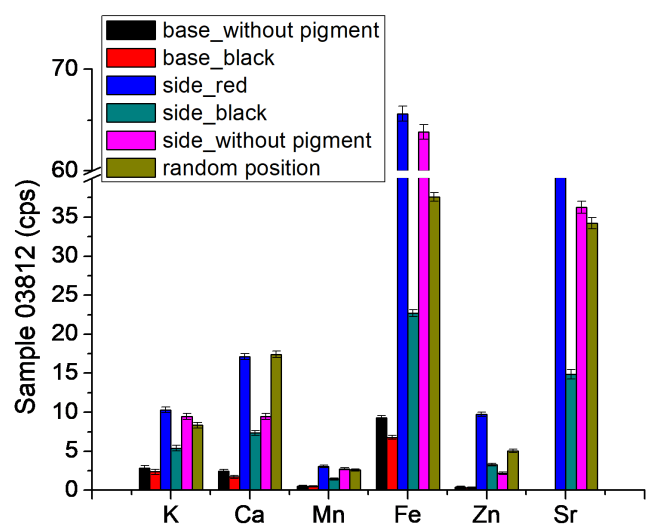

(b)

Source: The authors. 
Figure 5 - (a) Spectra and (b) peaks net area comparison for sample 03814.

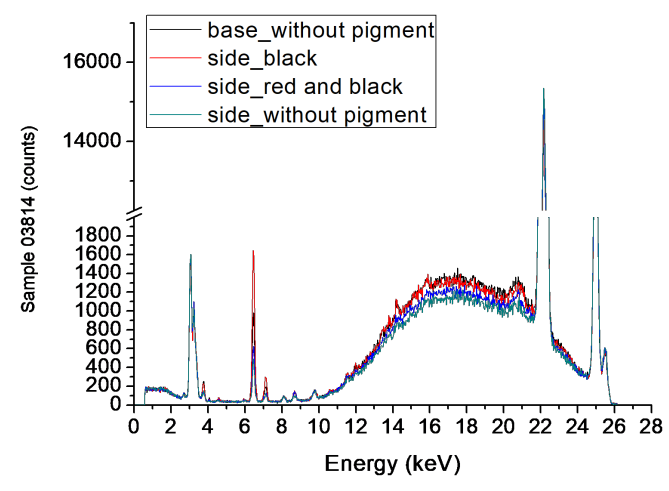

(a)

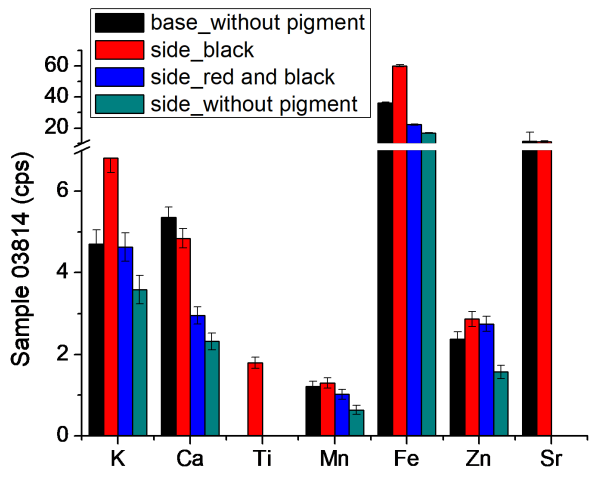

(b)

Source: The authors.

Figure 6 - (a) Spectra and (b) peaks net area comparison for sample 03819.

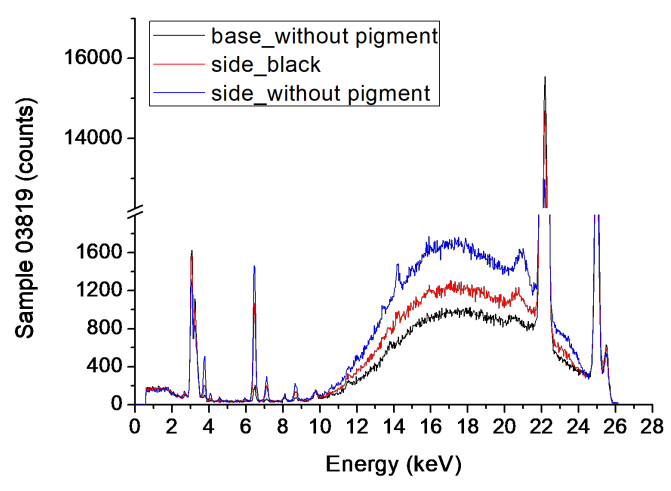

(a)

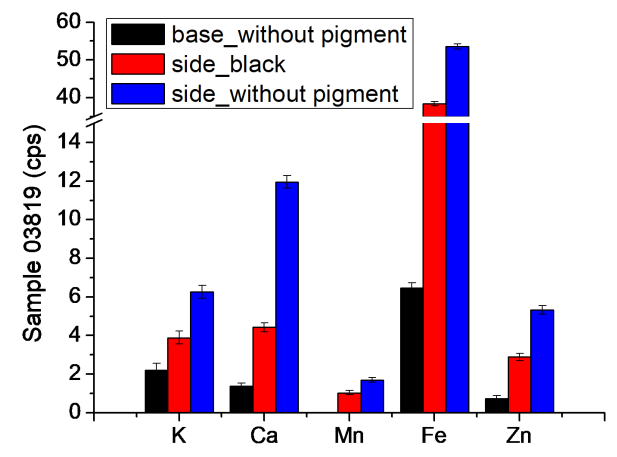

(b)

Source: The authors.

Figure 7 - (a) Spectra and (b) peaks net area comparison for sample 19477.

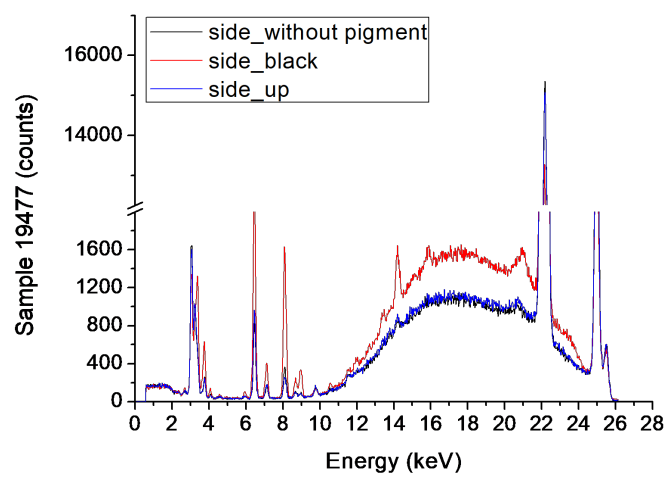

(a)

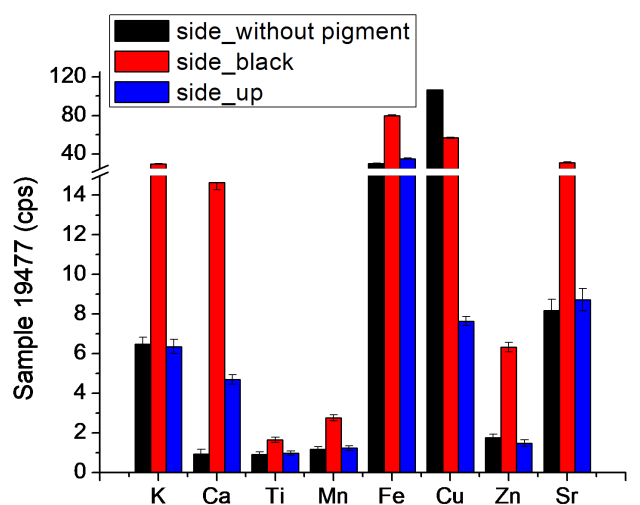

(b)

Source: The authors. 
Figure 8 - (a) Spectra and (b) peaks net area comparison for sample 03487.

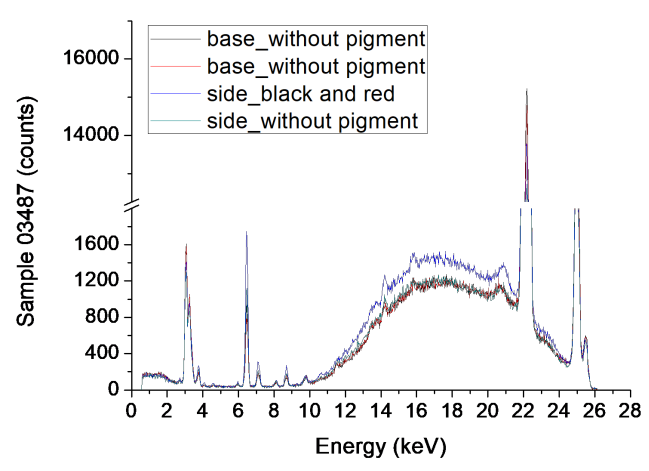

(a)

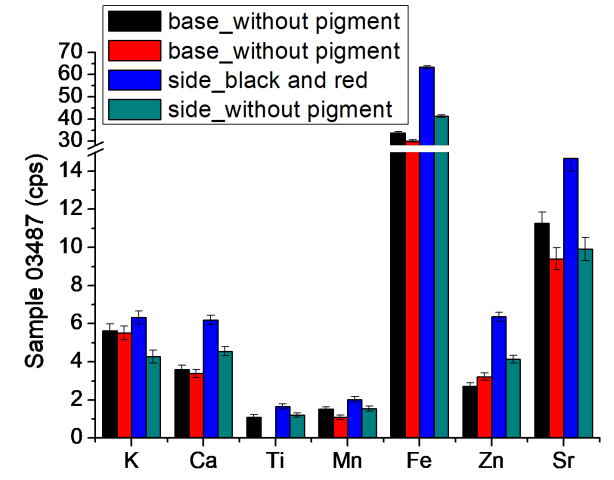

(b)

Source: The authors.

Figure 9 - (a) Spectra and (b) peaks net area comparison for sample 03869.

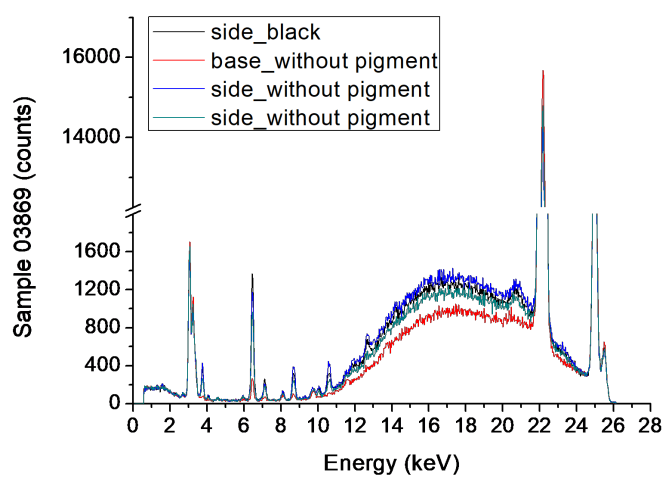

(a)

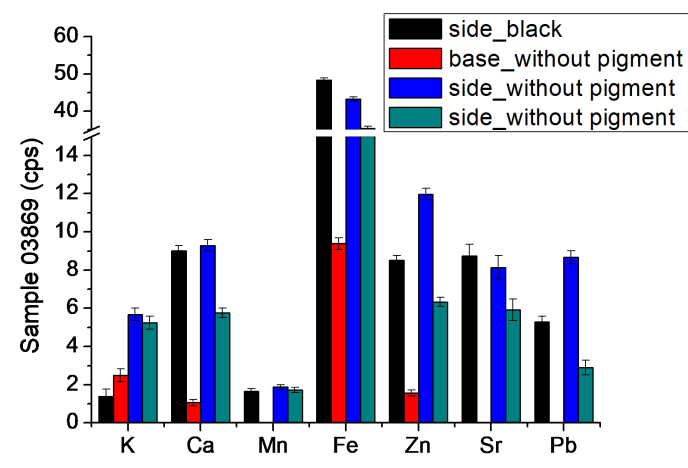

(b)

Source: The authors.

Figure 10 presents the PCA with the complete spectra data. The spectra were previously pre-processed with the mean center. It was possible to discriminate the samples in 3 groups.

Figure 10 - PCA score plot performed with complete spectra from the external bottom of each basket.

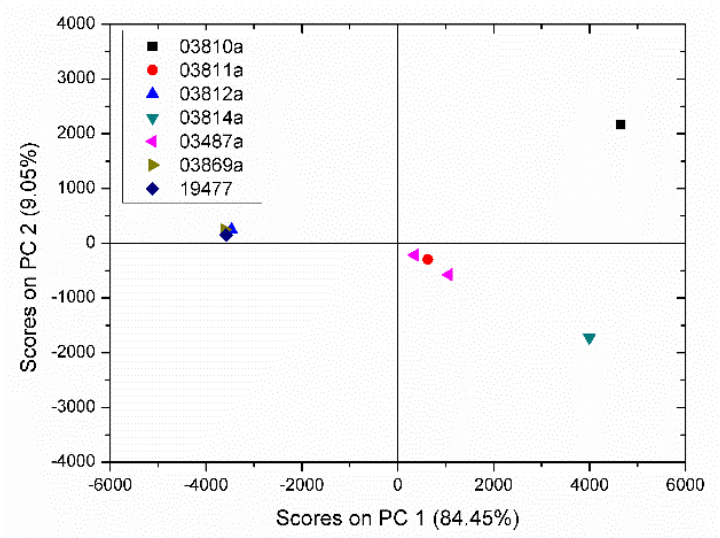

Source: The authors.
Since we do not have precise data regarding the provenance of the baskets, the PCA results can be addressed from a purely stylistic point of view. The distribution of samples over the Y-axis (PC 2) makes some sense since the baskets located above the positive direction of PC2 tend to display decoration in a rectangular shape, full panels of color which are reminiscent of Lake Titicaca Tiwanaku-style pottery and sculpture. Also, baskets with complex geometrical patterns woven based on small checkered fall within this region of the PCA space; similar baskets have been documented in a specific context in Pulacayo (southern Bolivian Altiplano) in association with Tiwanaku-style materials. Nowadays those baskets are exhibited in ASUR Museum, in Sucre city. At the same time, those baskets located in the negative direction of PC2 tend to display diamond-shaped motifs over a non-colored space, a style that we cannot identify but could presumably come from elsewhere. 
Raman spectroscopy results

Raman measurements sought to identify pigment characteristic bands. However, it was not possible to identify Raman bands in any of the dozens of measurements performed. It was measured regions of the raw material, regions with different pigments and colors, but in anyone a representative signal was obtained. Probably the fluorescence of the sample and the very thin and/or deteriorated pictorial layer thickness contributed to the non-detection of the characteristic bands with the portable spectrometer employed. Also, the low power of the portable spectrometer could not be appropriate.

\section{Conclusion}

This was the first time that tinctures used in Andean pre-Hispanic basketry from the MUSEF Collection were evaluated with non-destructive analytical techniques. The fact that the colored tones are organic, relates the examined basketry with the domain of textiles in a technical aspect. It suggests that vegetal fibers were dyed by soaking them in organic tinctures prior to the weaving process. However, differing from textiles, basketry was devoted mainly to the manufacture of recipients, which tend to imitate pottery shapes and functions.

It was not possible to determine the characteristics Raman bands of the fiber or pigment samples with the portable equipment employed. To obtain the pigments spectra, micro-Raman measurements should be performed. However, it must be done in a specialized laboratory with samples transportation.

The elements K, Ca, Ti, Mn, Fe, Zn and Sr were easily identified in the raw material and pigments using the $\mathrm{pXRF}$ equipment. The differences in the peaks intensity from colored points and raw material were not significantly different. Therefore, it was not possible to identify inorganic pigments in the samples.

Considering the exploratory multivariate analysis, PCA tends to separate at least two groups of basketry pieces within the sample set: one of them is stylistically related to the Middle Horizon, Titicaca Lake basin, and the other comes, presumably, from elsewhere. To establish this initial difference is highly important, although comparison with fragments or pieces from archaeological context will be necessary in order to test hypotheses on the causes of this difference. It may be linked to different regional traditions of pottery making, but factors such as chronology cannot be discarded.

\section{Acknowledgments}

The authors acknowledge the support of CNPq - INCT 464898/2014-5, as well as the Director Elvira Espejo Ayca, Chief of Museum and Inorganic Materials Curator of MUSEF.

\section{References}

ADOVASIO, J. M. Basketry technology: a guide to identification and analysis. Walnut Creek: Left Coast Press, 2010 .

AGÜERO, C. Los textiles de Pulacayo y las relaciones entre Tiwanaku y San pedro de Atacama. Boletín del Museo Chileno de Arte Precolombino, Santiago de Chile, v. 12, n. 1, p. 85-98, 2007.

APPOLONI, C. R. Recent developments in atomic/nuclear methodologies used for the study of cultural heritage objects. AIP Conference Proceedings, New York, v. 1529, n. 1, p. 30-39, 2013. DOI: https://doi.org/10.1063/1.4804077

BERENGUER, J. Tiwanaku: Señores del Lago Sagrado. Santiago de Chile: Museo Chileno de Arte Precolombino: Banco de Santiago, 2000.

BETANCOURT, C. J. La cerámica de la Loma Mendoza. In: MENDOZA, L. Las excavaciones del Instituto Arqueológico Alemán y de la Dirección Nacional de Arqueología en los años 1999-2002. La Paz: Plural Editores, 2015. p. 89-222.

CESAREO, R.; CASTElLANO, A.; CUEVAS, A. M. Energy dispersive $\mathrm{x}$-ray fluorescence analysis of thin and intermediate environmental samples. X-Ray Spectrom, [s. l.], 1998 v. 27, 257-261. DOI: https://doi.org/10.1002/(SICI)10974539(199807/08)27:4<257::AID-XRS295>3.0.CO;2-1.

CONNOLLY T. J. Implications of new radiocarbon ages on coiled basketry from the northern great basin. American Antiquity, Menasha, v. 78, p. 373-384, 2013. DOI: https://doi.org/10.7183/0002-7316.78.2.373.

CORBEIL, M.; POTTS, P. J.; WEST, M. Portable X-ray fluorescence spectrometry. Capabilities for in situ analysis. Anal. Bioanal. Chem, Heidelberg, v. 393, p. 1385-1386, 2009. 
HURTADO, R. Informe final de consultoría, Caracterización de fibras vegetales. La Paz: Museo Nacional de Etnografía y Folklore, 2017.

MELQUIADES, F. L.; APPOLONI, C. R.; ANDRELlO, A. C.; SPAGNUOLO, E. Non-destructive analytical techniques for the evaluation of cleaning and protection processes on white marble surfaces. Journal of Cultural Heritage, 2019, v.37, 54-62. DOI: https://doi.org/10.1016/j.culher.2018.10.013.

MOHOLY-NAGY, H.; MEIERHOFF, J.; GOLITKO, M.; KESTLE, C. An analysis of pXRF obsidian source attributions from Tikal, Guatemala. Latin American Antiquity, Washington, v. 24, p. 72-97, 2013. DOI: https://doi.org/10.7183/1045-6635.24.1.72.
PARREIRA P. S.; APPOLONI, C. R.; VIEIRA, R. M. L.; SCORZELLI, R. B.; LE CORRE L.; GUERRA M. F. Precious metals determination in ancient coins by Portable ED-XRF Spectroscopy with a $238 \mathrm{Pu}$ source. ArcheoScience, revue d'archéométrie, [Paris], v. 33, p. 313-318, 2009.

ROCABADO, P. A. Las sociedades formativas del altiplano circumtiticaca y meridional y su relación con el Norte Grande de Chile. Estudios Atacameños, San Pedro de Atacama, v. 21, p. 7-40, 2001.

SAGÁRNAGA, J. M. Avatares de una chullpa. Chachapuma, La Paz, v. 6, p. 56-57, 2014.

VAN GRIEKEN, R. E.; MARKOWICZ, A. A. Handbook of $X$-ray spectrometry. 2nd. New York: Marcel Dekker, 2002. 